\title{
ESPÍRITAS E CATÓLICOS: OS “ADVERSÁRIOS CÚMPLICES” NA FORMAÇÃO DO CAMPO RELIGIOSO BRASILEIRO
}

\author{
Célia da Graça Arribas *
}

Resumo: Para a análise do processo de formação do campo religioso brasileiro de fins do século XIX, este artigo toma por objeto empírico o desenvolvimento do conjunto da produção intelectual religiosa a fim de enxergar como e por quais personagens ele se fez realidade. Pretende-se, assim, analisar as disputas travadas através dos trabalhos de alguns dos primeiros espíritas brasileiros e seus rivais católicos, agentes de destaque cujas vozes ou penas acabaram por construir um terreno de operações para os confrontos entre distintas empresas de salvação, e não menos entre diferentes facções da mesma religião.

Palavras-chave: Sociologia da Religião. Espiritismo. Catolicismo.

Abstract: In order to analyze the formation of the Brazilian religious field by the end of the $19^{\text {th }}$ century, this article takes as the empirical object the religious literature produced by that time, taking into consideration how and by whom it became reality. Therefore, it is intended to examine the works of the first Brazilian Spiritists and their Catholic rivals, whose voices and pens helped to build an arena for the struggle among different Salvation enterprises, and not less between different factions of the same religion.

Keywords: Sociology of Religion. Spiritism. Catholicism.

Sabe-se que a condição política para a pluralidade religiosa no Brasil deuse basicamente com a instauração de um Estado republicano laico em 1889, condição esta, ratificada na nova Constituição aprovada dois anos depois. Mas, se antes já houvera, na Constituição de $1824^{1}$, certa abertura religiosa, foi somente com o fim do regime do Padroado da igreja católica que o campo religioso, em poucas décadas, começaria a funcionar de forma relativamente autônoma e

\footnotetext{
* Mestre em Sociologia pela Universidade de São Paulo. Contato: celiarribas@yahoo.com.br.

${ }^{1}$ No art. $5^{\circ}$ da Constituição outorgada de 1824 , a liberdade religiosa é concedida embora com restrições: os não católicos (para essa época leia-se: os protestantes) não podiam construir templos nem realizar seus cultos em espaço público.
} 
segundo a lógica de um mercado (desmonopolizado) de bens de salvação, dando origem assim ao nosso pluralismo religioso.

O Brasil ainda é, nos dias atuais, um país majoritariamente católico (74\% da população ${ }^{2}$. Certamente também o foi - pelo menos em termos estatísticos - durante os períodos da Colônia e do Império. No entanto, mesmo no período colonial, outras crenças religiosas, nativas ou trazidas da África, foram cultivadas por homens e mulheres, convivendo com o monolitismo da crença oficial. Somente a partir do século XIX, com a penetração de várias denominações protestantes ${ }^{3}$ e do espiritismo ${ }^{4}$, começaria o processo de formação explícita da heterogeneidade religiosa de uma nação que permanecia, a despeito da liberalização crescente, ainda oficialmente católica.

O movimento de pluralização só veio mesmo a se diversificar com a introdução por via imigratória - já sob a República laica - de crenças de grupos de imigrantes (japoneses, judeus, sírio-libaneses e outros), além de novas denominações protestantes e da difusão dos denominados cultos afro-brasileiros, antes confinados a comunidades isoladas. Hoje, após mais de um século dessa história, são muitas as crenças e as filosofias religiosas abraçadas pela população brasileira, enfraquecendo-se com isso a antiga hegemonia católica.

As manifestações religiosas que divergiam do catolicismo foram se afirmando e demarcando seu espaço em diferentes camadas da sociedade brasileira. Mas apesar da liberalização oficial, o preconceito real sofrido por essas religiões e a concorrência desigual que favorecia por inércia do privilégio a igreja católica

${ }^{2}$ De acordo com o censo de 2000 do IBGE.

${ }^{3}$ No Primeiro Reinado (1822-1831), a inserção protestante no Brasil deu-se através do protestantismo de imigração, sobretudo o Anglicano e o Luterano. Mas foi somente durante o Segundo Reinado (1840-1889), mais precisamente a partir dos anos 1870, que o Protestantismo de missão, o mais significativo em termos numéricos no Brasil, penetrou efetivamente em solo brasileiro, respaldado pelos conflitos entre a Igreja Católica e o Estado, cujo corolário foi a deno minada 'Questão Religiosa' de 1870.

${ }^{4}$ Ao longo deste artigo, o termo espiritismoserá utilizado para designar o corpo teórico-doutrinário elaborado na metade do século XIX por Allan Kardec, pseudônimo do pedagogo francês Hippolyte Léon Denizad Rivail, não tendo nenhuma relação com a umbanda - criada décadas depois no Brasil - ou com qualquer outra religião costumeiramente assim nomenclaturada pela bibliografia. 
eram realidades flagrantes. Perseguição e repressão policial ${ }^{5}$ de diversas religiões não-católicas caracterizaram o início histórico da constituição de um campo religioso tendencialmente concorrencial.

Sob este contexto, as religiões tiveram de se organizar e articular-se, fosse burocraticamente nos moldes convencionais de uma instituição, fosse doutrinariamente enquanto crença religiosa codificada e sistematizada. Sentido como um imperativo para que as recém-chegadas religiões pudessem se consolidar no campo religioso brasileiro, esse processo de racionalização e formalização institucional conduzido em dois níveis de organização, institucional e teórico, forneceu-lhes o aval indispensável para a sua existência e legitimidade.

Muito trabalho foi necessário para que isso viesse a se tornar uma realidade. Ea fonte principal de energia viria diretamente dos intelectuais das religiöesinteressados na defesa e na validação de suas crenças e instituições. Foram eles que pensaram e articularam cada religião nas suas mais diversas dimensões de atuação. Foi principalmente deles o "trabalho religioso" (BOURDIEU, 2001) que produziu o nosso pluralismo religioso. Mas ao contrário do que superficialmente se pode concluir, esse não foi um trabalho tranquilo, simplesmente de ordenação e de estruturação. Entender o processo de formação da diversidade religiosa brasileira implica explicitar os diversos mecanismos de disputas e de alianças, de embates ideológicos e de tomadas de posição, de justificação e de hierarquização que fizeram do campo religioso brasileiro um terreno de operação para as lutas entre diferentes empresas de salvação.

Pensando desta maneira, vários dos trabalhos acadêmicos interessados de uma forma ou de outra no surgimento de novas crenças e de novas doutrinas no Brasil tenderam a contemplá-lo sobretudo do ponto de vista de suas causações externas $^{6}$, deixando de forma secundária, de um lado, a análise das dinâmicas de estruturação interna das próprias religióese, de outro, a análise das relações

${ }^{5} \mathrm{O}$ Código Penal de 1890 estabelecia nos artigos 156, 157, 158 punições às práticas mágicas: ao curandeirismo, ao charlatanismo e ao espiritismo. Além disso, religiões consideradas "não-mágicas" também sofreram perseguições, como foi o caso do protestantismo (ALVES, 1982).

${ }^{6}$ Aubrée e Laplantine (1990); Brown (1985, 1997); Camargo (1961, 1973); Cavalcanti (1983); Concone (1987); Damazio (1994); Doyle (1981); Giumbelli (1997); Hess (1987a, 1987b); Machado (1983); Maggie (1992); Negrão (1994); Ortiz (1988); Santos (1997); Schritzmeyer (2004); Silva (2005); Stoll (1999); Warren $(1984,1986)$. Cabe salientar aqui que tais estudos 
entre os agentes envolvidos na produção e reprodução dos contingentes religiosos. Em outras palavras, as lutas e disputas simbólicas e materiais internas à própria dinâmica do campo religioso merecem maior atenção para que se possa chegar a uma compreensão mais abrangente acerca do nosso pluralismo religioso. Seria mais fácil, dessa maneira, enxergá-las enquanto partes constituintes de um campo relativamente autônomo que estava se formando.

Cada vez que se fazia necessária a defesa de certas crenças, de certos ideais ou de certos dogmas, um meio certeiro era utilizado por esses intelectuais: a imprensa. Foi sobretudo através dos conflitos literários entre os diferentes segmentos religiosos que aos poucos foi sendo criado um terreno no qual mecanismos de argumentação e de validação puderam ser postos e expostos em jogo, dando origem assim ao próprio jogo.

Embora muito antes da instauração da República Brasileira já existisse uma mídia religiosa - pastorais, catecismos, boletins, periódicos, todos católicos -, foi somente com a entrada em cena de novos movimentos e institutos religiosos, que este campo passou a se formatar em moldes plurais e a procurar subsistir segundo a lógica de um mercado (desmonopolizado) de bens de salvação, cujas estruturas e engrenagens passaram a garantir a sua própria existência, de acordo com o modelo de um campo relativamente autônomo.

Desse modo, para a análise do processo de formação do campo religioso brasileiro de fins do século XIX, talvez fosse interessante tomar por objeto empírico o desenvolvimento do conjunto da produção intelectual religiosa, a fim de enxergar como através de quais personagensele se fez realidade. Pensando assim, chegamos finalmente ao objetivo deste artigo: analisar as disputas em questão por meio dos trabalhos empreendidos por alguns dos primeiros espíritas brasileiros e seus rivais católicos- agentes de destaque cujas vozes ou penas acabaram por construir um terreno de operações para as disputas entre distintas empresas de salvação, e não menos entre diferentes facções da mesma religião.

privilegiam - cada qual a seu modo e em momentos diferenciados - a análise dos fatores de constrangimentos externos da constituição do nosso pluralismo religioso, ao ressaltarem nesse processo a atuação das esferas médica, jurídica, científica e jornalística sobre as recém-chegadas religiões. Entre outros motivos, acabaram automaticamente deslocando para último plano uma análise do ponto de vista do especificamente religioso. 


\section{O CASO ESPÍRITA}

A introdução e aceitação crescente do espiritismo no Brasil serviram para acentuar um movimento mais amplo de pluralização confessional, de que fazem parte outras doutrinas e sistemas religiosos. Foi aqui que o Livre des esprits teve um dos muitos destinos de parada, como não podia ser diferente, já que existiam estreitas ligações entre as camadas intelectuais do Brasil e da França. Pessoas e idéias francesas se faziam sentir em suas influências na academia, nas artes e mesmo na política brasileiras. Entre 1853 e 1854 foram publicadas no Jornal do Commércio, do Rio de Janeiro, no Diário de Pernambuco, de Recife, e em O Cearense, de Fortaleza as primeiras notícias sobre os fenômenos das "mesas girantes” ocorridos nos Estados Unidos e na Europa (BARBOSA, 1987).

Mas em se tratando de uma teoria que se definia ao mesmo tempo como religiosa, científica e filosófica (KARDEC, 2001), era de se esperar que fosse absorvida e desenvolvida de diversas formas. E foi o que aconteceu por aqui. Cada tipo de camada social buscou enfatizar uma das suas possíveis vertentes, ora pendendo mais ao cientificismo, ora à face religiosa, ora às ideias puramente filosóficas. Se hoje conhecemos o espiritismo como uma religião entre diversas outras em oferta no mercado religioso brasileiro, é porque por detrás de todo esse processo de introdução e legitimação da teoria espírita no Brasil, um grupo frente aos demais conseguiu vencer a disputa e alcançar o poder simbólico de ditar o que era (ou não) espiritismo.

A entrada do espiritismo em terras brasileiras contou com o importante papel dos imigrantes da colônia francesa do Rio de Janeiro - então capital do Império -, composta por jornalistas, comerciantes e professores. Tendo seus primeiros adeptos originários desse comitê, o espiritismo dava os seus primeiros passos com a publicação de Les temps sont arrivés (1860), livro escrito em francês pelo professor Casimir Lietaud, diretor do Colégio Francês, estabelecimento de ensino dos mais conceituados da Corte. Casimir e outros imigrantes franceses

${ }^{7}$ Publicado na França em 1857 e tido como um dos cinco "livros da codificação" do espiritismo de Allan Kardec, Le livre desespritsinaugura a nova teoria, complementada posteriormente pelos: Le livre desmediums(1861), L'evangile selon le spiritisme (1864), Le cielet l'enfer (1865) e La genèse (1868). 
agrupavam-se no Courrier du Brésil, cuja redação tinha uma linha claramente anticlerical. Foi nessa roda que a teoria espírita encontrou grande receptividade. Mas, ao contrário do que hoje entendemos por espiritismo, naquele instante ele não surgia como uma nova opção religiosa. Estava ali entrelaçado com as modernas tendências políticas e filosóficas, em particular com o socialismo (AUBRÉE e LAPLANTINE, 1990). A explicação das desigualdades sociais era relacionada às diversas existências da alma, e nesse grupo mesclavam-se às leituras de Kardec as leituras de Saint-Simon, Charles Fourier e Pierre Leroux, os denominados socialistas utópicos. Entretanto, ainda que o grupo tivesse sido composto por pessoas de prestígio econômico, social e cultural, a colônia francesa restringiu suas relações com o espiritismo em algumas reuniões esotéricas e a poucas publicações, limitando sua circulação e sua receptividade naquele momento. Além disso, era um tanto quanto inusitado para a sociedade da época a discussão sobre socialismo e reencarnação. O socialismo não tinha grande repercussão no debate políticoideológico do Brasil escravocrata do século XIX, mais compromissado com questões institucionais e jurídicas do que com revolução social. E como, nesses precisos termos, não se mostrava como opção religiosa, a Igreja do Rio de Janeiro não fez grandes oposições ao espiritismo ao longo da década de 1860.

E assim, mesmo não tendo se alastrado pela Corte inteira, a influência social desses franceses facilitou a penetração do espiritismo pelo menos entre a elite imperial. Em conversas, ainda que tímidas, nas ruas ou em pequenas sessões espíritas, a nova teoria passava a angariar os seus primeiros adeptos brasileiros, pessoas de influência social e que por isso não sofriam qualquer tipo de repressão.

Seria, entretanto, em outra província, que o espiritismo ganharia maior exposição pública. Oficialmente, a eclosão do espiritismo deu-se no ano de 1865 em Salvador, cidade onde foi fundado o primeiro grupo espírita, o Grupo Familiar do Espiritismo. Luís Olímpio Telles de Menezes, seu fundador e autor d'O espiritismo - introdução ao estudo da doutrina espírita (1865) - obra que reunia excertos traduzidos do Livre des esprits-, mantinha contatos com Casimir Lietaud no Rio de Janeiro e com vários espíritas da França. A partir de seus esforços, a posição do espiritismo se inverteu: o Rio passou a ser umas das províncias da nova corte, a Bahia. 
Telles de Menezes foi criado no seio de uma família católica, como era de se esperar, já que o catolicismo era a religião oficial do Império e a que detinha o monopólio religioso. Figura típica de uma camada social nascente em Salvador, Telles de Menezes, após desistir da mesma carreira de militar do pai, por falta de aptidão, passou a se dedicar ao magistério e ao jornalismo, escolhas profissionais que o sistema provinciano lhe permitia.

Muito embora não proviesse da camada socialmente mais privilegiada, no sentido forte do termo, Telles de Menezes reunia em torno de si um capital social bastante ampliado, uma vez que freqüentava as rodas aristocráticas. Com tamanho respaldo social de homens importantes da economia e da política baianas, Telles começava sua empreitada espírita com grande peso legitimador decorrente dessas relações. Entretanto, foi somente com a tradução de alguns dos trechos do livro de Kardec que Telles de Menezes abriria ao público o acesso à nova forma de visão de mundo, indo além dos círculos aristocráticos e intelectuais. Seu trabalho de difusão das idéias espíritas desenvolveu-se através do "meio material que a Providência sabiamente nos oferece para levar, rapidamente, a palavra da verdade à inteligência e ao coração de todos os homens [...] a Imprensa”. ${ }^{8}$

Em 8 de março 1869, Telles reuniu seus companheiros no Grêmio de Estudos Espiríticos da Bahia, para anunciar a fundação do primeiro jornal espírita brasileiro, O Echo d'Além-Túmulo - Monitor do Espiritismo no Brasil. Ojornal bimestral circulou não só na Bahia, mas em outras partes do território nacional. Imprimia-o a Tipografia do Diário da Bahia.

A participação de Telles de Menezes nas fileiras socialmente mais privilegiadas possibilitou-lhe o manuseio de alguns dispositivos essenciais para a divulgação e expansão do espiritismo em terras brasileiras. Além de professor primário, estenógrafo, funcionário da Assembléia Legislativa e Oficial da Biblioteca Pública da Bahia, Telles de Menezes era também jornalista e escrevia em vários periódicos baianos, entre eles, o Diário da Bahia, o Jornal da Bahiae $A$ Época Literária, chegando inclusive a publicar um romance chamado Os Dois Rivais. Não é sem explicação, o fato de Telles portar consigo os conhecimentos necessários a respeito dos mecanismos de funcionamento da imprensa, capital

${ }^{8}$ Echo d'Além-Túmulo, setembro de 1869 (grifos do autor). 
que lhe possibilitou ao fim e ao cabo não só criar um jornal, como também angariar fundos econômicos e respaldo organizacional.

A fundação de um periódico espírita no Brasil foi vista positivamente desde lá do outro lado do Atlântico. O Echo d'Além-Túmuloteve a sua aparição registrada na seção "Bibliographie" da Revue Spirite de outubro de 1869, e em novembro do mesmo ano, foi feita a seu respeito uma extensa apreciação de quatro páginas, nas quais incluía a citação de longo artigo extraído dele e vertido para o francês. Entretanto, a maior resposta ao trabalho de Telles de Menezes não veio de Paris, veio sim de mais perto: do clero baiano. Uma Pastoral lançada em 16 de junho de 1867, pelo arcebispo da Bahia D. Manuel Joaquim da Silveira, foi a réplica mais imediata da igreja frente à dilatação do espiritismo. Por irônico que pareça, coube exatamente à igreja católica o gesto de entreabriras portas ao espiritismo para que ele pudesse entrar no campo religioso.

Filosófico, científico e religioso desde o seu começo, o espiritismo ainda não tinha se definido essencialmente como religião no Brasil até aquele momento, muito embora contivesse em si a possibilidade de vir a sê-lo, já que uma de suas definições era a religiosa. Mesmo com os trabalhos de Telles, ninguém se dizia espírita como afirmação de uma opção religiosa em detrimento do catolicismo.

Reconhecendo a expansão do espiritismo em terras brasileiras, a Pastoral dialogava principalmente com a tradução de Kardec feita por Telles nos seguintes termos:

Nessa capital publicou-se um pequeno livro com o título - Filosofia Espiritualista - o Espiritismo - cujas perniciosas doutrinas, contra toda expectação, têm tomado incremento, pondo-se em prática certas superstições perigosas e reprovadas, que estão no domínio do público; e no interesse da vossa salvação, amados Filhos, Nós julgamos conveniente dirigir-vos contra esta Carta Pastoral, para prevenir-vos contra os principais erros que contém esse pequeno livro, e

${ }^{9}$ A Revue Spirite, fundada em 1858 por Allan Kardec, foi o primeiro e ainda existente periódico espírita. A Sociedade Anônima do Espiritismo, da qual fazia parte l'Union Spirite Française et Francophone de Paris, que então dirigia a Revue Spirite, agradeceu epistolarmente a Telles de Menezes, por seu secretário geral A. Desliens, a remessa do primeiro número d'O Echo d'AlémTúmulo. 
contra as superstições, que segundo as doutrinas nele contidas se estão praticando, como se nos tem informado, e do que já não é possível duvidar (MACHADO, 1983, p. 84).

Assim, para impedir a disseminação das idéias de Kardec, nada melhor do que expor contrariamente a elas os dogmas da igreja, linguagem específica de um diálogo religioso. Mas esse confronto não quer dizer que os espíritas por algum instante tivessem negando a sua religião católica e contra ela investindo pesados esforços, pelo menos por enquanto. Os primeiros trabalhos em nome do espiritismo definiam-no como apenas uma correção necessária, ou melhor, uma atualização aos tempos modernos dos dogmas católicos e não propriamente como uma nova religião. Aliás, Telles de Menezes reivindicava até com certa insistência a sua condição de católico "de nascimento e de crença” (MACHADO, 1983, p. 89), e ainda voltou a insistir ao afirmar que "o Espiritismo e o Catolicismo são a mesma Igreja de Nosso Senhor Jesus Cristo: somente estão mudados os tempos e as palavras: o Espiritismo é o tradutor fiel, pelos enviados de Deus, das doutrinas do Evangelho" (idem).

Mas certamente houve disputas de ordem dogmática, e foram dois os pontos mais explosivos, porque pretendiam inovar as próprias crenças católicas: o primeiro era sem dúvida a reencarnação, que na doutrina de Allan Kardec está entrelaçada à ideia de justiça divina; o segundo inquietava ainda mais a igreja católica, ou pelo menos o arcebispo D. Manuel: a manifestação dos espíritos. A invocação dos mortos, que já era praticada pelos negros, entendida como pura superstição e tolerada pela igreja - que a via como válvula de escape para aliviar a tensão da vida no cativeiro - ameaçava invadir a casa grande.

Com as traduções de Telles de Menezes, a dimensão social que o espiritismo tomava, por ter atingido setores para além das camadas mais privilegiadas da sociedade baiana, também causava preocupações reconhecidas na Pastoral:

Os efeitos mais claros do Espiritismo são, na ordem religiosa, a negação cada vez mais geral do Cristianismo como obra divina, e como religião positiva: o enfraquecimento do temor dos juízos de Deus" (MACHADO, p. 85, grifos do autor). 
Escrito por Telles de Menezes, o folheto O Espiritismo. Carta ao Excelentísimo e Reverendíssimo Senhor Arcebispo da Bahia, D. Manuel Joaquim da Silveira não tardou a ser publicado. Lançado no mesmo ano da Pastoral, foi a primeira formulação brasileira sobre as teorias espíritas.

Mas enganar-se-á aquele que pensar que as disputas pararam por aí. Muito pelo contrário, já que o diálogo entre católicos e defensores do espiritismo apenas começava. A tréplica não tardou a chegar. Só que não veio das penas do arcebispo que, atendendo ao pedido de seus fiéis e auxiliares, preferiu deixar a peleja a cargo do Padre Juliano José de Miranda. Responder o próprio arcebispo à carta de Telles de Menezes seria como rebaixar-se na dignidade arquiepiscopal.

Ocorre que Telles de Menezes não pretendia, naturalmente, acabar com a instituição católica. O apego e o respeito dos primeiros espíritas ao catolicismo aparecem claramente em seus escritos, mostrando que ainda o espiritismo nem pretendia ser uma religião, nem se posicionava no campo religioso enquanto tal, e muito menos estava preocupado em tomar o lugar da igreja. A força do catolicismo vigorava com espantosa naturalidade entre os primeiros adeptos das ideias espíritas, explicitada nessas palavras de Telles de Menezes: "a dignidade do homem, a fé católica e a obediência, que prestamos a V. Exa., como humilde ovelha de seu rebanho, impõe-nos o sagrado dever de patentear a razão, que nos levaram a esposar a salutar e evangélica doutrina do espiritismo" (MACHADO, p. 100, grifos nossos). Aliás, o apelo à razão como forma de ajustar aos novos tempos os velhos dogmas católicos expressava o ideal iluminista ${ }^{10}$ do pensamento de Telles de Menezes e dos primeiros espíritas, ideal retraduzido agora em palavras obsequiosas segundo as etiquetas demandadas no campo religioso com dominância católica.

\footnotetext{
${ }^{10}$ Reconhecer a herança intelectual do Iluminismo presente nas obras de Allan Kardec e, por conseqüência, de alguns seguidores seus, é situá-la no bojo do processo de "desencantamento do mundo". Observando o aspecto metodológico de Kardec, é possível afirmar a significativa influência das principais vertentes do pensamento iluminista - racionalismo, experimentalismo, evolucionismo - sobre o espiritismo. Não apenas no método de elaboração, o espiritismo é herdeiro do pensamento iluminista: é-o também em toda a sua teorização. Allan Kardec, respirando o clima cultural da França do Século das Luzes, não poderia trabalhar de outra forma a não ser postulando que: "fé inabalável é somente aquela que pode encarar a razão, face a face, em todas as épocas da Humanidade". Essa é nada menos que a epígrafe escolhida a dedo por Kardec para abrir seu Evangelho, O Evangelho segundo o espiritismo.
} 
A Breve Apreciação da Carta do Sr. Luís Olimpio Telles de Menezes Sobre o Espiritismo ao Exmo. e Rev. Sr. Arcebisposaiu no segundo semestre de 1867 e foi escrita por Juliano José de Miranda, um jovem padre de apenas 25 anos. Nela, Pe. Juliano buscava defender a fé católica e combater o espiritismo com toda a garra de um iniciante quando vê uma chance se abrir. Mais uma vez, a preocupação girava em torno das concepções da reencarnação e da preexistência da alma, além do fato mais repudiado por D. Manuel: a comunicação com os mortos. Mas sem o saber, tanto D. Manuel quanto o Pe. Juliano, além de toda a ala católica contrária às concepções espíritas, acabavam concedendo ao espiritismo um espaço no campo religioso ao colocar no e em jogo seus conceitos e noções. Assim, sem ter consciência do fato, ambos os lados e parcela da sociedade baiana assistiam ao primeiro ato da polêmica entre católicos e os defensores do espiritismo. Mas nem todo o clero teria uma atitude semelhante à do Pe. Juliano e à do arcebispo da Bahia. Foram muitos os padres que se interessaram pelas novidades espíritas nessa fase baiana, o que indicava a existência de diferentes posicionamentos dentro da igreja. O duelo tornava-se cada vez mais empolgante com a exposição das diversas verdades. Nessa toada, quem ia se realçando mais e mais era a teoria espírita.

A luta pela manutenção do monopólio religioso por parte da igreja católica - luta que habita o campo de produção dos bens de salvação - contribuía para o próprio fortalecimento da legitimidade em nome da qual ela era conduzida. A igreja enquanto ortodoxia do campo, necessitava da heresia, porque a oposição entre uma e outra implica sempre o reconhecimento dos interesses que estão em jogo. Ao negar uma oposição - no caso, o espiritismo - a igreja ao mesmo tempo em que se reafirmava no campo, onde começava a perder espaço, ${ }^{11}$ acabou por conferir voz ao espiritismo, isto é, um espaço lídimo na disputa. As bases da contenda, sintomaticamente, estavam nos trechos bíblicos, o que acabava conduzindo a certos impasses. As diferentes interpretações criaram barreiras intransponíveis, referentes aos postulados de cada jogador, que amoldava os fatos à sua exegese. Mas tudo isso teve um resultado bastante específico. A leitura

\footnotetext{
${ }^{11}$ Respaldados pela Constituição de 1824, na qual fora concedida, ainda que de forma restrita, a liberdade religiosa, o protestantismo conseguiu inserir-se no Brasil, ameaçando com isso o monopólio da igreja católica.
} 
herética e a ortodoxa da Bíblia, sobretudo dos Evangelhos, reforçava justamente um ponto extremamente importante para a própria manutenção do campo religioso: a disputa garantia a fé - confiança absoluta e inabalável em determinadas crenças produzidas e reproduzidas pelos porta-vozes. Nesse sentido, D. Manuel Joaquim da Silveira, Padre Juliano José de Miranda, Luís Olímpio Telles de Menezes e tantos outros envolvidos na questão eram, portanto, adversários cúmplices.

Pensando assim, pode-se afirmar que o tão almejado êxito dos envolvidos na disputa - e conseqüentemente $o$ êxito das empresas de salvação às quais pertenciam - consistia exatamente em adquirir para seu trabalho e para si a força da crença, ou seja, a fé - um reconhecimento absoluto. Para tanto, fazia-se necessária a existência de uma espécie de poder "mágico" na relação entre 1) os interesses dos participantes, 2) o poder simbólico que manipulavam e 3) a crença dos demais nesse poder. Pois, para que esse poder se perpetuasse, isto é, para que a fé existisse, os agentes especializados nesse trabalho tinham que conseguir mantêla desconhecida, ou seja, evidente. Mas, desse modo, eles não garantiam somente a fé; garantiam também a sua própria existência e validavam o seu trabalho religioso. Os investimentos no jogo, isto é, as lutas que travaram e que tinham por finalidade obter o monopólio da definição do modo legítimo de produção dos bens de salvação, contribuíam para reproduzir continuamente a crença no jogo, o interesse pelo jogo e pelas apostas; lutas estas que são, pelo menos parcialmente, o produto do próprio jogo.

Em 1871, Telles de Menezes e seus adeptos resolveram pedir autorização para o funcionamento da Sociedade Espírita Brasileira. Mesmo declarando ser uma sociedade literária e beneficente, a aprovação foi negada pelo parecer de ninguém menos que $\mathrm{D}$. Manuel Joaquim. Seu argumento não poderia ser outro que o católico, isto é, político-religioso. O espiritismo era assim "um atentado formal contra a verdade católica [...]. Uma sociedade, cuja doutrina tem por fim contrariar a Religião do Estado, é contra o mesmo Estado" (idem, p. 98). Importa aqui, não perder de vista, que o arcebispo fala em Religião do Estado, logo mobilizando uma indistinção de esferas "pré" liberdade religiosa. É um argumento religioso, mas não puramente religioso, pelo fato mesmo de não haver ainda um campo religioso totalmente constituído. 
O espiritismo não encontrara até então uma forma de se legitimar em terras brasileiras. Ainda não se posicionava de fato como religião; também não estava no campo político nem filosófico, como interpretaram os imigrantes franceses; e no campo científico também não conseguiu lugar, recebendo vários ataques discriminatórios. O movimento espírita baiano não pôde institucionalizar o espiritismo. Não obstante, com Telles de Menezes à frente, chamou a atenção do restante do Brasil e concorreu para repropagar as idéias espíritas, especialmente na Corte. São dele as seguintes palavras:

Os preconceitos, infelizmente arraigados no ânimo do maior número, têm sido um dos grandes obstáculos à propagação das salutares e regeneradoras doutrinas da filosofia espirítica. A fiel exposição dessas doutrinas não está ao alcance das multidões, porque as obras fundamentais não se acham traduzidas na língua vernácula; entretanto, preciso é aqui notar o valioso serviço que prestou $\mathrm{O}$ Echo d'Além-Túmulo - cuja publicação foi interrompida -, levando a idéia espirítica a todos os pontos do Brasil, de modo que hoje já se agita ela em todas as províncias, e já nalgumas se têm formado grupos e sociedades, como no Pará, Maranhão, Pernambuco e no Rio de Janeiro, onde as idéias espiríticas mais extensamente têm progredido [...] (WANTUIL, 2002, p. 585, grifos nossos).

\section{DE VOLTA AO RIO DE JANEIRO}

O espiritismo já era então conhecido pela nata social, camada na qual havia conquistado admiradores e praticantes, "[...] e isso não é difícil de provar, se observa que o Espiritismo fez adeptos principalmente nas classes elevadas da sociedade" ${ }^{12}$ A princípio, o que mais lhes interessou foi o caráter cientificista que traziam as idéias espíritas. Mas embora contasse com o interesse de alta estirpe, o espiritismo era estudado e praticado de forma ainda velada. Isso porque, enquanto teoria composta de uma face religiosa, começava a sofrer o repúdio da igreja católica, ciosa de manter o monopólio religioso; enquanto agente

${ }^{12}$ Echo d'Além-Túmulo, setembro de 1869. 
provocador de fenômenos físicos, era acusado pelo campo científico de fraudulento e explorador da credulidade pública.

As suas várias formas de aceitação provocaram a formação de diversos grupos. A dispersão do espiritismo em vários segmentos mostrava como ainda não havia, naquele momento, uma definição legítima do que era espiritismo e em qual campo ele iria atuar. Seu panorama no final do século XIX se mostrava bastante rico, pelo menos no que diz respeito à quantidade de grupos que o seguiam. Havia o grupo dos científicos, também chamado de Espiritismo Científico, que abrangia alguns subgrupos, tendo destaque os Psiquistase os Ocultistas. Esses espíritas estavam exclusivamente preocupados com o que chamavam de experiência fenomenológica. Sua atenção estava voltada para os "fenômenos" espíritas, ou seja, para as aparições dos espíritos e seus efeitos (materialização, sonambulismo, hipnotismo). Desprezavam a filosofia espírita e principalmente seus aspectos religiosos. O grupo dos místicos ou religiososera o mais numeroso e se atinham à moral cristã. Dentre os subgrupos, destacavam-se os roustainguistas, os ismaelinos, os kardecistas, os teosofistase os swedenborgistas (ABREU, 1996, p. 9). Espiritismo Purosignificava que nem era científico, nem místico. O grupo, com tendências ao olhar mais filosófico, foi o que menos força teve na disputa simbólica da definição do que era (ou não) espiritismo. Talvez por ter sido o mais tolerante, não investiu pesadamente nesse jogo assim como o fizeram os científicos e os místicos.

Em 2 de agosto de 1873 surgia a primeira sociedade espírita da Corte, Sociedade de Estudos Espiríticos - Grupo Confúcio, dedicada ao "estudo dos fenômenos relativos às manifestações espíritas, bem como o de suas aplicações às ciências morais, históricas e psicológicas" (WANTUIL, 2002, p. 121). Um dos mecanismos mais eficazes, postos em prática pelo Grupo Confúcio, foi a tradução das obras de Allan Kardec. Coube então ao médico e Secretário Geral do grupo, o Dr. Joaquim Carlos Travassos, a tarefa de trazer à língua portuguesa, em meados da década de 1870, O Livro dos Espíritos, O Livro dos Médiuns, O Céu e o Inferno e $O$ Evangelho segundo o Espiritismo, obras dadas à luz por intermédio da conceituada Editora B. L. Garnier, composta, entre outros editores, por Bittencourt Sampaio, jurisconsulto, magistrado, político, alto funcionário público, jornalista, literato e também membro do Conselho Fiscal do Grupo Confúcio. 
Para além das traduções de Kardec, foram também criados aparelhos responsáveis pela circulação das ideias. Daí a fundação da Revista Espirita - publicação mensal de estudos psicológicos, editada entre os anos de 1875 e 1876, cujo conteúdo abrangia desde artigos traduzidos da Revue Spirite e de outros jornais estrangeiros, até comentários e explanações doutrinárias. Antônio da Silva Neto, fundador da revista, escrevia na primeira edição: "O Espiritismo é uma ciência de observação; portanto está comprometido no quadro das ciências positivas". ${ }^{13}$ No entanto, apesar de seu trabalho de defesa do espiritismo, a revista teve curta duração, bem como o Grupo Confúcio, que se extinguiu em 1879. Aliás, três anos antes, o grupo já havia sofrido com a dissidência de alguns membros, os mesmos responsáveis pela fundação da Sociedade de Estudos Deus, Cristo e Caridade, dirigida por Bittencourt Sampaio e pelo advogado Antonio Luis Sayão, ambos mais interessados no aspecto religioso do espiritismo. Mas essa Sociedade, por sua vez, também sofreria com disputas internas. A divisão entre os seus membros provocou uma separação irreconciliável, entre os que pretendiam fazer do centro uma quase academia de ciência, e os que davam proeminência ao fato religioso, mesma divisão que provocara o fim do Grupo Confúcio. Assim, seu nome passou a ser Sociedade Acadêmica Deus, Cristo e Caridade, atendendo à vontade do grupo dos científicos e tendo à frente o professor Angeli Torterolli, uma das figuras mais expressivas do movimento espírita da época e uma das mais desconhecidas hoje, por mais paradoxal que isso possa parecer. Pedro Richard, espírita religioso, lamentou o fato anos mais tarde dizendo que não era possível conceber o espiritismo dessa forma: "Como se Deus, Cristo e Caridade pudessem ser acadêmicos, colegas de pobres pecadores ignorantes". ${ }^{14}$

Antonio Luiz Sayão que tentara, sem êxito, recompor a antiga Sociedade de Estudos Deus Cristo e Caridade, acabou fundando com Bittencourt Sampaio e outros o Grupo dos Humildes (1880), que mais tarde veio a se chamar Grupo Ismael, uma das agremiações mais importantes de espíritas cariocas, integrada tempos depois à Federação Espírita Brasileira (FEB), fundada em 1884.

Juntamente com esses grupos, proliferavam vários outros, sendo comum a presença da mesma pessoa em vários deles, indicando que, apesar da diversidade

${ }^{13}$ Revista Espírita, $\mathrm{n}^{0} .1$, janeiro de 1875.

${ }^{14}$ Reformador, 15 de setembro de 1901. 
de interpretações e de práticas filiadas ao espiritismo, é difícil reduzílas, engessálas às categorias criadas pelos próprios espíritas - científicos, místicos, puros, etc. -, categorias que colocam em jogo os temas em disputa, mas que não se excluem mutuamente. Convém salientar que entre os espíritas as ações de autoclassificação e, consequentemente, de desclassificações mútuas não foram atos isolados, mas um processo no qual se percorreu uma sequência de elos significativos. Mas, admitir a inexistência de interferências entre eles, seria ignorar a própria experiência empírica. Mais apropriado seria então, afirmar que havia um terreno comum, no qual os diversos adeptos transitavam com bases na tematização "ciência", "filosofia" e "religião" em suas variadas e complexas articulações.

Por volta de 1889 havia só no Rio de Janeiro cerca de 35 grupos espíritas (GIUMBELLI, 1997, p. 62), fato que demonstrava um movimento totalmente disperso. Eram membros desses diversos grupos médicos, engenheiros, advogados, militares, funcionários públicos, jornalistas e professores (ARRIBAS, 2008, p. 82). A maioria dos principais líderes espíritas ocupava posições sociais relativamente privilegiadas, o que garantia aos grupos de que participavam a possibilidade de se beneficiarem de recursos materiais e de redes de relações importantes para a legitimação da causa espírita.

Assim disperso, o movimento espírita só iria conseguir delimitar-se e legitimar-se com o surgimento de uma associação que se pretendesse reguladora e unificadora das ideias espíritas; uma entidade que se propusesse a representar os diversos grupos e a ser o instrumento de divulgação da doutrina. Nesses exatos termos definia-se a Federação Espírita Brasileira (FEB).

A FEB foi criada em 1884, no Rio de Janeiro, por Augusto Elias da Silva, que um ano antes havia fundado $O$ Reformador, revista que passou a ser desde então o órgão oficial da Federação Espírita e que muito contribuiu no processo de legitimação e de delimitação do que viria a ser o espiritismo em terras brasileiras. Nela, foram realizadas 23 conferências públicas sobre o espiritismo nos anos de $1885,1886,1887$, dadas por diretores e outras pessoas ligadas ou não à FEB. Empreendimento de êxito, pelo menos conforme o Reformador, ${ }^{15}$ essas

\footnotetext{
${ }^{15}$ Menciona-se no Reformadorde 15/08/1886 e de 15/12/1887 que o número médio de participantes de cada conferência era de 500 pessoas.
} 
conferências conseguiram atrair para o espiritismo um bom número de pessoas, tornando-se uma via de acesso privilegiada à orquestração de concepções e orientações gerais compartilhadas pelos membros da FEB.

Para além da preocupação de unificar o movimento espírita, O Reformador surgia também com o intuito de defender o espiritismo dos ataques discriminatórios dos católicos, expressos através de duas pastorais distribuídas pelo bispo do Rio de Janeiro ao Episcopado Brasileiro. A primeira delas foi a Pastoral da Diocese de São Sebastião do Rio de Janeiro, redigida por D. Pedro Maria de Lacerda, datada de 15 de julho de 1881. A segunda, igualmente do mesmo prelado e com data de 15 de junho de 1882, apresentava um tom ainda mais taxativo e enfático. D. Pedro Lacerda não poupou sequer um instante a utilização de adjetivos desqualificadores das práticas e concepções espíritas. Daí terem sido os primeiros números do Reformador ocupados em boa parte com críticas a essas pastorais e com refutações a artigos escritos em $O$ Apóstolo, órgão católico bastante difundido à época. Dessa forma, apareciam nas páginas do Reformador.

A primeira parte da Pastoral, conquanto cheia de citações dos Evangelistas, não parece ser escrita sob a inspiração do espírito do Cristianismo, como era de se esperar do Ministro da Religião do Manso e Humilde [...]. A idéia dominante em toda a pastoral mostra claramente que foi o espírito do judaísmo que a bafejou, principalmente no parágrafo consagrado ao Espiritismo.

Tornar-se-ia por demais longo este artigo se passássemos agora a analisar ponto por ponto a primeira, a segunda e a terceira parte da Pastoral, que nós por amor do Bispado deveríamos qualificar ao menos de malfadada; por amor ao homem devemos denominar - bendita - lembrados do Sermão da Montanha. E maior terá o seu mérito se por causa dela o digno Prelado Brasileiro for estudar a ciência espírita. ${ }^{16}$

Réplicas espíritas não ficaram sem tréplicas católicas. Foram escritos logo em seguida uma série de artigos n’O Apóstolo intitulados $\mathrm{O}$ espiritismo, em consecutivos números no ano de 1883. Ainda que contrários à ideia de reencarnação

${ }^{16}$ Reformador, 21 de janeiro de 1883. 
e à prática de evocação dos mortos, o prelado repisava a sua posição e ressaltava que a Igreja também respeitava o Século das Luzes e a liberdade de consciência, bandeiras-chaves trazidas pelo espiritismo. Aliás, mesmo que manifesta no campo religioso, era essa a postura mais válida naquela época, a de se enfileirar nos ideais iluministas e cientificistas, sobretudo no de progresso. E colocando tudo que é contrário à Igreja num só bolo, bem distinto e oposto a ela, escrevia o clero:

Todos os erros são os mesmos. Mudam somente o nome e se cobrem com a capa do progresso e da ciência [...]. E com outros muitos princípios errôneos, ímpios e contraditórios, pretende o espiritismo destruir todos os dogmas, insinuar-se e fazer prosélitos à moda de Maomé, descobrindo os mais largos horizontes de gozos e prazeres nessas sucessivas vidas [...]. Vamos ver no último quartel do XIX reviverem os prestígios da nigromancia, [...] ou então ser ensinada e propagada a metempsicose.

Amamos o progresso, procuramos as luzes e respeitamos a liberdade de consciência bem entendida, como a observa a Igreja, mas é nosso princípio: Diligile homines interficite errores.

Não tratamos de indivíduos. Discutimos princípios, e eis porque não nos toca o que nos dirigiu o Reformador. A caridade não consiste em ficar-se surdo ao ensino herético e considerar aceitável uma doutrina condenada, perversa e nociva à moral e à sociedade. ${ }^{17}$

Por conta talvez dessa sua ligação com a Federação Espírita Brasileira, o que lhe garantiu respaldo institucional, $O$ Reformador não passaria por apuros como ocorreu com os demais periódicos da mesma época, sobrevivendo, desta maneira, até os dias de hoje. Assim, como porta-voz desta instituição - que se tornava cada vez mais poderosa - e do espiritismo que aí vinha se formando, o órgão passou a mediar o seu programa espírita.

Tem-se a impressão de que, a partir de então, o espiritismo começava a tomar um rumo diferente do que fora em Salvador. O enfoque baiano alterava-se. O espiritismo no Rio de Janeiro parecia identificar-se agora com uma realidade

${ }^{17}$ O Apóstolo, 18 de março de 1883 (grifos do autor). 
diferente. A discussão, doravante, enveredava-se por outros caminhos, rumo a uma formatação mais consistente do que viria a ser o espiritismo oficial aqui no Brasil. O trabalho intenso e interessado de certos "espíritas religiosos" e as condições sociais de vida da população urbana do Rio favoreciam a sua expansão, sobretudo a expansão de uma das facetas do espiritismo: a religiosa, ou melhor dizendo, a terapêutica-religiosa (DAMÁZIO, 1994).

\section{A PRODUÇÃO DE UM ESPIRITISMO RELIGIÃO}

Já é sabido que a condição política para a pluralidade religiosa no Brasil deu-se basicamente com a instauração de um Estado laico. Diante desse quadro, vale a pena insistir nas modificações ocorridas na atuação e no discurso da Federação Espírita Brasileira, que logo se dimensionaram para fazer frente à nova situação políticoinstitucional. Se antes da República, os espíritas recebiam ataques constantes da imprensa, reclamações de médicos e mesmo acusações de charlatanismo, foi somente a partir de 1890, com a aprovação do Código Penal, que os espíritas passaram a sofrer judicialmente processos condenatórios. ${ }^{18} \mathrm{Com}$ isso, houve uma reorientação da atuação institucional da FEB, que por estratégia passou a enfatizar no espiritismo seu caráter especificamente religioso, conduta que acabou modificando definitivamente a presença (e o modo de presença) do espiritismo no Brasil. Se a FEB passou a assumir a função de representação aos olhos das agremiações espíritas e diante do poder judiciário - para defender espíritas das acusações penais -, ela só o fez por conta de dois motivos: o primeiro diz respeito ao cabedal de forças e capital sociais que agregava à figura de seus membros - advogado, médicos, jornalistas; segundo, porque ao ressaltar e reapresentar seu caráter religioso, o espiritismo passava a atuar como religião, entronizando de forma legítima uma nova posição - uma nova opção - no campo religioso brasileiro, agora um pouco mais plural.

Todavia, cabe ressaltar enfaticamente que para além dos fatores externos existentes e expressivos a respeito do processo de "religiosificação" do espiritismo (com o perdão do grosseiro neologismo), internamente ao movimento

\footnotetext{
${ }^{18}$ Sobre o tema, ver Giumbelli (1997), Maggie (1992) e Schritzmeyer (2004).
} 
espírita, a ala religiosa ganhava cada vez mais força na disputa de dizer o que era (ou não) espiritismo, angariando deste modo mais vigor e mais autoridade para conseguir sua consagração. Assim, ao escolher a via religiosa, a FEB passou a seguir a lógica e as regras próprias do campo em questão, em vista da legitimidade necessária para a consolidação da recém-assumida, ou melhor, autoreivindicada religião. Foi dessa forma que o espiritismo conseguiu proteger-se e legitimar-se no Brasil, definitivamente (ARRIBAS, 2008, p. 185-206).

Mas se é fato que o espiritismo, por possuir ascendência européia, carregava consigo certo prestígio que pode ter facilitado seu expandir-se nas camadas mais privilegiadas de então, sua origem européia, por outro lado, e o peso legitimador dessa origem parecem ter pesado menos que o fato de ele ter desenvolvido uma conformação específica no processo de sua inserção em um novo quadro de relações sociais. Foi nesse processo que entraram em cena os diversos grupos e a disputa que travaram entre si com o objetivo de alcançar a primazia do discurso espírita. Em meio a tais disputas, coube a alguns agentes especializados a produção de instrumentos e os meios adequados à organização, transmissão e inculcação de uma doutrina cada vez mais assumidamente "doutrina”, ou seja: cada vez mais "inventada” como religião. Assim, a produção de instrumentos, tais como, jornais, revistas, diários, boletins, informativos, congressos, livros, dogmas, agremiações, sociedades etc., foi tanto maior nas situações iniciais de introdução por que passou o espiritismo quanto mais necessário se fez enfrentar as vertentes concorrentes, internas ou externas a ele. ${ }^{19}$

$\mathrm{O}$ ideal da FEB de reunir os grupos no Rio de Janeiro e rediscutir as orientações doutrinárias comuns era certamente antigo entre os espíritas dessa instituição ${ }^{20}$. Mas somente em 1889 surgiu uma entidade capaz de torná-lo efetivo, o Centro Espírita do Brasil, cuja criação fora apoiada pelo então presidente da FEB, Dr. Adolfo Bezerra de Menezes. A resolução posta no parecer elaborado

19 "A Federação [Espírita Brasileira, no final do século XIX] publicou uma estatística de jornais espíritas do mundo inteiro. Pois bem: existem no mundo 96 jornais e revistas, sendo que $56 \mathrm{em}$ toda a Europa e 19 só no Brasil. [...] Ainda em 1900, no seu relatório ao Congresso Espírita e Espiritualista de Paris, a Federação acusava adesões de 79 associações e 0 aparecimento de 32 jornais e revistas de propaganda [...]" (RIO, 2006, p. 270).

${ }^{20}$ Em alguns números do Reformador (como por exemplo nos de 01/01/1885 e de 15/05/1887), nota-se mais enfaticamente a presença de propostas de "união" e "consagramento". 
pelo Centronão poderia ser outra: era necessário unificar o método de trabalho. Assim, submetido a um novo prisma estrutural, o espiritismo, através do trabalho interessado e incessante de seus líderes, deveria então articular o formato de um núcleo centralizadorjuntamente com um processo de normatizacão doutrinária. Coube ao então cognominado "Allan Kardec brasileiro", o Dr. Bezerra de Menezes, a tarefa de dar esse passo e inserir definitivamente o espiritismo no campo religioso brasileiro (ARRIBAS, 2008, p. 90-149).

\section{CONSIDERAÇÕES FINAIS}

Longe de ser exaustivo, este artigo teve como proposição apontar para a necessidade de uma análise da dinâmica de estruturação interna do espiritismo recém-chegado ao Brasil Oitocentista, bem como de uma análise relacional entre alguns dos agentes envolvidos na produção e reprodução do campo religioso brasileiroem vias de formação. Detectar algumas das tensões existentes e alguns dos enfrentamentos emergentes nesse campo levou-nos a compreender que não só havia uma lógica inerente a ele, como também que esta lógica acabou por produzir os seus próprios mecanismos de funcionamento e de manutenção.

Desta maneira, pode-se concluir que a autonomia do campo religioso afirmou-se inicialmente, e afirma-se em parte até hoje, 1) de um lado, na tendência dos especialistas de se encerrarem na referência autárquica ao saber religioso já acumulado e no saber hermético de uma produção de início destinada aos demais produtores. Entretanto, por mais que seja clara a ruptura entre os especialistas e os leigos, a produção do campo religioso distingue-se do campo de produção intelectual especificamente falando. Isto porque, 2) de outro lado, os especialistas religiosos, por mais que tentem, dedicando ainda parte de seus escritos a isso, não podem restringir sua produção ao saber exclusivamente esotérico, isto é, dedicado apenas aos produtores. Eles têm de se sacrificar por necessidade às exigências dos leigos. Foi por isso também que o espiritismo não pôde ser especificamente nem uma ciência nem uma filosofia, como queriam alguns. Isto por dois processos concomitantes: primeiro, ao abrir inevitavelmente a sua produção aos leigos a fim de se expandir e de se propagar, o espiritismo teria passado de uma produção esotérica para outra exotérica, e, segundo, ao 
dialogar com os católicos, por mais especialista que fosse o clero, este também não fazia e não faz parte do campo de produção intelectual. Por conseguinte, entre outros motivos, o espiritismo não se constituiu no Brasil enquanto uma nova posição nem no campo científico, nem no campo filosófico. Ou seja, por não realizarem uma produção estritamente ministrada a círculos fechados de ouvintes - como é forçosamente o caso da produção intelectual propriamente dita -, os espíritas tiveram imperiosamente que produzir escritos passíveis de serem ministrados a um público bem mais amplo. Assim, ao invés de uma produção que poderia ser hermética, mais íntima, destinada a um grupo seleto, o espiritismo adotou uma mais vulgar, mais ordinária, pensada exatamente para ser exposta, talvez pela demanda das "implicações morais" de uma de suas facetas (a religiosa), às quais os espíritas tanto fizeram e ainda fazem referência. Deste modo, o campo de produção de bens de salvação tem a particularidade de posicionar-se entre uma produção esotéricae uma produção exotérica. Daí que, se de um lado, o campo religioso já tem certa autonomia por criar e possuir uma produção acumulativa destinada inicialmente aos demais produtores (esotérica), por outro lado, quando essa produção se expande por necessidade ao círculo dos leigos (exotérica), sobretudo em uma situação de pluralismo religioso competitivo, essa autonomia se reforça, já que há uma transformação nas relações de produção simbólica, conducentes à constituição de um verdadeiro campo de forças e tensões. Assim, entre produtores e leigos/consumidores, as relações reflexivas de criação e de recepção se estabelecem de maneira a compor uma lógica cada vez mais particular de funcionamento. E são, exatamente, as engrenagens desse exercício que tornam ainda mais autônomas a produção dos bens religiosos.

Assim, a concorrência que se estabeleceu entre os agentes e as empresas no e emjogo era a concorrência pelo monopólio do exercício legítimo do poder de modificar em bases duradouras e em profundidade a prática e a visão de mundo dos leigos. No entanto, faz-se necessário - e mesmo imprescindível lembrar que essa autonomia é sempre relativa, no sentido de que ela também se dá, ou melhor, ela também se pauta em partes nas suas mais diversas relações com os demais campos de produção simbólica. Neste sentido, como pudemos observar, os fatores externos serão sempre reestruturados conforme a lógica 
interna do campo religioso, por meio exclusivamente de seus agentes especializados. Por isso que a dinâmica de produção/reprodução do campo tomou continuamente características especiais relacionadas ao seu momento histórico de delimitação e às disposições próprias de seus agentes.

\section{REFERÊNCIAS}

ABREU, Canuto. Bezerra de Menezes. São Paulo: Edições FEESP, 1996. ALVES, Rubens. Protestantismo e repressão. São Paulo: Ed. Ática, 1982.

ARRIBAS, Célia da Graça. Afinal, espiritismo é religião? A doutrina espírita na formação da diversidade religiosa brasileira. Mestrado (Dissertação em Sociologia) - Faculdade de Filosofia, Letras e Ciências Humanas, Universidade de São Paulo, São Paulo, 2008.

AUBRÉE, Marion e LAPLANTINE, François. La Table, le livre et les esprits. Paris: S.l. Jean Claude Lattes, 1990.

BOURDIEU, Pierre. Gênese e estrutura do campo religioso ; Uma interpretação da teoria da religião de Max Weber. In: . A economia das trocas simbólicas. São Paulo: Ed. Perspectiva, 2001.

BROWN, Diana (org.). Umbanda e política. Rio de Janeiro: Ed. Marco Zero, 1985.

CAMARGO, Cândido Procópio Ferreira de. Kardecismo e umbanda. São Paulo: Pioneira Ed., 1961.

. Católicos, protestantes, espíritas. Petrópolis: Editora Vozes, 1973.

CAMURÇA, Marcelo A. Entre a graça e a evolução. Revista Eclesiástica Brasileira, vol. 58, fasc. 230, p. 385-402, 1998.

. Fora da caridade não há religião! Lócus - Revista de História, vol. 7, n. 1, p. $131-154,2001$.

CAVALCANTI, Maria Laura. O mundo invisível. Rio de Janeiro: Ed. Zahar, 1983. 
CONCONE, Maria Helena Vilas Boas. Umbanda: Uma religião brasileira. São Paulo: FFLCH/USP-CER, 1987.

DAMAZIO, Sylvia F. Da elite ao povo. Rio de Janeiro: Bertrand Brasil, 1994.

DOYLE, Athur Conan. Le histoire du spiritisme. Traduzido do inglês por Claude Gilbert. Monaco: Éditions du Rocher, 1981.

FERNANDES, Magali, Oliveira. Luiz Olympio Telles de Menezes: Os primeiros momentos da edição kardecista no Brasil. Dissertação (Mestrado em Comunicação) - Escola de Ciências e Arte, Universidade de São Paulo, São Paulo, 1993.

GIUMBELLI, Emerson. Ocuidado dosmortos Rio de Janeiro: Arquivo Nacional, 1997.

HERVIEU-LÉGER, Danièle; WILLAIME, Jean-Paul. Max Weber (1864-1920). Gènese religieuse de la modernité occidentale, rationalisation et charisme. In:__. Sociologies et religion. Approchesclassiques. Paris : Presses Universitaires de France, 2001.

HESS, David. The many rooms of spiritism in Brazil. Luso-Brazilian Review, XXIV, n.2, p. 15-34, 1987a.

. O espiritismo e as ciências. Religião e Sociedade. Rio de Janeiro, n. ${ }^{\circ} 4(3)$, p. 40-54, $1987 \mathrm{~b}$.

KARDEC, Allan. O livro dos espíritos. São Paulo: LAKE, 2001.

LEWGOY, B. Os espíritase as letras. Tese (Doutorado em Antropologia) - Faculdade de Filosofia, Letras e Ciências Humanas, Universidade de São Paulo, São Paulo, 2000.

LÖWY, Michael; DIANTEILL, Erwan (orgs.). Pierre Bourdieu (1930-2002), explorateur du champ religieux. In: Sociologies et religion. Approches dissidents. Paris: Presses Universitaires de France, 2005.

MACHADO, Ubiratan. Os intelectuais e o espiritismo. Rio de Janeiro: Edições Antares, 1983. 
MAGGIE, Yvonne. Medo do feitiço. Rio de Janeiro: Arquivo Nacional, 1992. MICELI, Sérgio. A elite eclesiástica brasileira. Rio de Janeiro: Ed. Bertrand Brasil, 1988.

NEGRÃO, Lísias Nogueira. Entre a cruz e a encruzilhada. São Paulo: EDUSP, 1996.

ORTIZ, Renato. A morte branca do feiticeiro negro. São Paulo: Brasiliense, 1988. PIERUCCI, Antonio Flávio. Secularização segundo Max Weber. In: SOUZA, Jessé (org.). A atualidade de Max Weber. Brasília: Editora da UNB, 2000. RIO, João do. As religiões no Rio. Rio de Janeiro: José Olympio, 2006.

SANTOS, José Luis dos. Espiritismo: uma religião brasileira. São Paulo: Moderna, 1997.

SCHRITZMEYER, Ana Lúcia Pastore. Sortilégio de saberes. São Paulo: IBCCRIM, 2004.

SILVA, Luiz da. Espiritismo. Londrina: Eduel, 2005.

STOLL, Sandra Jaqueline. Entre doismundos. Tese (Doutorado em Antropologia) - Faculdade de Filosofia, Letras e Ciências Humanas, Universidade de São Paulo, São Paulo, 1999.

WARREN, Donald. A terapia espírita no Rio de Janeiro por volta de 1900. Religião e Sociedade, Rio de Janeiro, n. ${ }^{0} 11(3)$, p. 56-83, 1984.

. A medicina espiritualizada. Religião e Sociedade, Rio de Janeiro, n. ${ }^{0} 13(1)$, p. 88-107, 1986.

WEBER, Max. Sociologia da religião. In: . Economia e sociedade. Brasília: Ed. Universidade de Brasília, 2000.

WANTUIL, Zeus. Grandes espíritas do Brasil. Rio de Janeiro: Federação Espírita Brasileira, 2002. 
